Cruft R (2015) Human Rights Law Without Natural Moral Rights, Book review of: The Heart of Human Rights, Allen E. Buchanan, Oxford: Oxford University Press, 2013, 336 pp. ISBN 9780199325382, Ethics and International Affairs, 29 (2), pp. 223-232.

Publisher policy allows this work to be made available in this repository. Published in Ethics \& International Affairs / Volume 29 / Issue 02 / Summer 2015, pp 223-232Copyright @ Carnegie Council for Ethics in International Affairs 2015. The original publication is available at: DOI: http://dx.doi.org/10.1017/S0892679415000088 


\section{Human Rights Law Without Natural Moral Rights}

The Heart of Human Rights, Allen Buchanan (New York:Oxford University Press, 2013),336 pp., $\$ 45$ cloth.

\section{Rowan Cruft}

In this latest work by one of our leading political and legal philosophers, Allen Buchanan outlines a novel framework for assessing the system of international human rights law-the system that he takes to be the heart of modern human rights practice. Buchanan does not offer a full justification for the current system, but rather aims "to make a strong prima facie case that the existing system as a whole has what it takes to warrant our support of it on moral grounds, even if some aspects of it are defective and should be the object of serious efforts at improvement” (p. 173).

The book is brimming with new ideas and insights, and I see three main claims that have particularly interesting implications. First, Buchanan argues against what he calls the "Mirroring View":

To justify an international legal human right typically involves defending the claim that a corresponding moral human right exists. The qualifier "typically" is designed to accommodate the fact that some who hold this view acknowledge that in some cases a justified international legal human right does not mirror a moral human right, but is rather either (a) a specification of a moral human right . . . or (b) something that is instrumentally valuable for realizing a moral human right ... (p. 17).

Buchanan makes a plausible case that many philosophers working on the moral foundations of human rights erroneously assume the Mirroring View, including James Griffin, Joseph Raz, and John Tasioulas. He could equally have targeted Carol Gould, Martha Nussbaum, Amartya Sen or Carl Wellman. Buchanan's main argument against the Mirroring View starts from the premise that any moral right has to be "solely subject-grounded," that is, it has to be justified by what it does for the individual right-holder-where this might involve serving the right-holder's interests, protecting her freedom or needs, or the like (p. 59). But many international legal human rights have "corresponding duties the fulfilment of which requires large-scale social investment and limitations on the liberty of large numbers of people" (p.62). As examples, Buchanan mentions the legal human right to health, which requires governments to set up vaccination programs to deliver herd immunity, and the legal human right to democracy, which entails duties on governments to hold fair elections with appropriate nationwide logistics in place (pp. 61-62). ${ }^{1}$ Such legal human rights, with their demanding corresponding duties, cannot be justified simply by what they do for the individual 
subject. As he writes, “To put the point bluntly: No matter who you are, you are not important enough to justify a set of duties that correlate with the panoply of legal rights [protected by international human rights law]" (pp.63-64). Buchanan concludes that international legal human rights must in most cases be justified by how they serve "the interests and autonomy of large numbers of people" (p. 64), and this means that they cannot be grounded as reflecting or operationalizing pre-legal moral rights. Thus, the Mirroring View is false.

Buchanan goes on to outline a plurality of reasons in favor of a system of international legal human rights that are independent of pre-legal moral rights: Such a system encourages improvements in domestic bills of rights; enhances states' legitimacy by providing for the independent adjudication of claims made against them; supplies doctrinal resources for improving the humanitarian law of armed conflict; provides a legal framework for dealing with global problems; and makes democracies responsive to the needs of foreigners as well as their own citizens. Buchanan claims that the human rights system is a necessary condition on the justifiability of the global order of states. This order vests huge power in sovereign states by conferring conventional-legal rights of control, rights over resources, and borrowing rights on whatever body is in de facto control of a territory; the limits imposed on states by human rights are a minimal condition on the justifiability of this system.

In sketching his range of reasons for having a system of international legal human rights, Buchanan takes the system to be defined by two characteristic functions: "(a) helping to ensure that each individual has the opportunity to lead a minimally good or decent life (the well-being function) and (b) affirming and protecting the equal basic moral status of each individual" (p. 313). Buchanan thinks that an international legal system with these two functions can be defended on the grounds he offers without appealing to pre-legal moral rights.

The arguments for the role and importance of the second function regarding equal basic status are, I suggest, the second of the book's three most significant contributions. Buchanan believes that ensuring opportunities for minimal wellbeing could be achieved without granting each individual equal basic status: for example, it could be achieved in certain caste or patriarchal societies. But Buchanan sees the securing of equal basic status as an essential function of international human rights law, a function with its own distinct importance.

The book's third significant innovation concerns what Buchanan calls the "Metacoordination View" of legitimacy. ${ }^{2}$ This is the view that standards of legitimacy for an institution are normative standards that we consider appropriate to require of an institution in order for it to merit our respect as a solution to a coordination problem in which serious costs and important benefits are at stake. To put it in Buchanan's words, "institutions cannot generally function so as to coordinate our behavior in beneficial ways - or at least cannot do so without 
excessive costs in terms of coercive enforcement-unless enough people can converge in their individual judgments as to whether the institution is worthy of support. Criteria of legitimacy serve as coordination points to solve this metacoordination problem" (p. 179).

Legitimacy assessments express "a compromise between the need to have a functioning institution and the desire to impose normative requirements on it" (p. 195). Legitimacy in this sense is something that we decide to adopt as a standard for a given institution, rather than something that is discovered. We decide that such-and-such standards are appropriate to require of an institution if it is to merit our respect as an authority in domain so-and-so. What legitimacy standards we should impose will depend partly on the nature of the domain (which will make certain purported standards of legitimacy inherently unacceptable), but also on our particular concerns, needs, and attitudes toward risk in a given context.

Two appealing conclusions follow from this general view of legitimacy. First, appropriate standards of legitimacy for the state need not be appropriate for nonstate institutions, such as human rights institutions. So Buchanan argues, for example, that democratic accountability is not essential for the legitimacy of each and every part of the United Nations' institutional human rights apparatus, even if such accountability is necessary for a state's legitimacy. Similarly, even if possession of enforcement power turns out to be essential to a state's legitimacy, possession of such power may not be necessary for the legitimacy of international legal human rights institutions.

Second and relatedly, the legitimacy of international legal human rights institutions is, as Buchanan puts it, an "ecological" matter: that is, the legitimacy of a given institution will depend on how it coheres with other institutions, and the legitimacy of the latter will in turn depend on how they interact with the first institution. For example, Buchanan suggests that "with respect to the treaty drafting groups and the treaty bodies, if we view them in isolation, rather than as elements in a broader network that encompasses international, regional, and national institutions, we will underestimate their legitimacy" (p. 197). Buchanan is especially doubtful about the legitimacy of the Security Council, due primarily to its lack of accountability and transparency, and its failure to live up to its public claim to protect against major human rights violations. But Buchanan notes that on his view, "the illegitimacy of even an institution as important as the Security Council need not undermine the legitimacy of other parts of the system" (p. 203). Following careful investigation he concludes that treaty-drafting groups and treaty bodies can qualify as legitimate according to the standards appropriate to their functions.

\section{Assessing the argument for the centrality of equal basic status}


Each of Buchanan's three central claims is attractive. The Metacoordination View releases the concept of legitimacy from the straitjacket of state-focused theories of political obligation.

Buchanan's resulting position makes an institution's legitimacy significantly harder to assess (in that one cannot simply "plug in" a pre-prepared theory of the legitimacy of the state), but the flexibility and context-dependence brought by the Metacoordination View feel appropriate to the complexity of the legitimacy of international institutions. However, I am skeptical about Buchanan's claim for the centrality of equal basic status to international legal human rights. Of course many human rights protect our equal basic status, and of course such equal status is morally important. But I am not convinced by Buchanan's claim that the "minimum well-being" function of human rights is independent of the "equal status" function. The argument for this claim is that a system of legal rights that secures people's minimal well-being need not secure equal basic status:

Some of the major human rights conventions ... include what I have called strong rights against discrimination on grounds of race or gender . . . These cannot plausibly be understood as serving only to ensure the conditions for being able to lead a minimally good or decent human life, because people can lead a minimally good or decent human life and yet be subject to some forms of discrimination. This would be the case, for example, if wellpaid, educated women receive lower salaries than men, simply because they are women, or when highly successful people of color suffer similar "soft" discrimination. Nor is it convincing to argue that people cannot lead minimally good or decent lives unless they not only have the same rights as others but also have the same rights with the same scope and weight and subject to the same conditions of derogation and also have strictly equal access to remedies for violations of their rights (p. 89).

The claims in the final sentences above seem correct to me: it is unconvincing to say that people cannot lead minimally good lives if they are subject to "soft" discrimination or fail to possess the same legal rights as others. But this does not warrant the conclusion that strong equal status laws must play a function other than the protection of minimal well-being. Notice that it is equally unconvincing to say that people cannot lead minimally good lives if rights that are clearly targeted at protecting their wellbeing are violated, or if they lack wellbeing-protecting legal rights. For example, some people who are subjected to torture recover and lead minimally good lives overall; some people denied wellbeing-protecting legal rights (people in regimes that permit forced marriage, for example) also manage to lead minimally good lives. Of course, a large number of people whose wellbeing-protecting rights are violated, or who lack such rights, will have their lives severely impaired as a result. But not everyone will. Throughout history, a vast number of people have had their wellbeing-protecting rights violated, or have lacked legal rights protecting their wellbeing. I venture that nonetheless many such people have lived minimally good lives.

This point does not, I think, undermine Buchanan's claim that one of the distinctive features of human rights is to protect people's wellbeing. But it undermines the claim that possession of or respect for human rights is necessary for a person to possess minimal wellbeing. Legal human 
rights protect wellbeing by making it more likely that people will attain minimal wellbeing, rather than by guaranteeing it. But once this point is conceded, Buchanan's argument for the distinct importance of equal status fails. People who suffer soft discrimination might well go on to lead minimally good lives, as Buchanan notes; but this is consistent with the thesis that rights against such discrimination function to protect minimal wellbeing. No rights with the minimal wellbeing function guarantee minimal wellbeing: they simply make such wellbeing more likely. And rights against soft discrimination — along with other equal status rights — clearly do this: rights securing equal status make it more likely that people will attain minimal wellbeing. On this basis, someone who wanted to take the protection of minimal wellbeing as the sole function of human rights law seems able to accommodate equal status rights without regarding "securing equal status" as an independent function for human rights law. ${ }^{3}$

There might well be other arguments for the conclusion that securing equal basic status is a distinct function of human rights law, irreducible to the wellbeing function. For example, one might directly argue that there are strong wellbeing-independent reasons to ensure that each human, qua human, has rights to equal basic status. Buchanan touches on such an argument when he makes a moral case that all beings who can "participat[e] in practices involving rational accountability" (p. 137) hold equal fundamental moral status. I have argued, contra Buchanan, that the prominent equal status rights in international human rights law do not require such a direct grounding: they can be grounded on the importance of securing minimal wellbeing for all. But an independent grounding for them might well be attractive nonetheless.

One could develop Buchanan's argument for our equal basic moral status as an argument for moral rights to equal basic status - moral rights that international human rights law should reflect. The idea that international human rights law should reflect or embody moral human rights is the Mirroring View, and we should note that while Buchanan rejects its universality, he allows that some international legal human rights might be justified in this way - as reflections of pre-legal moral rights. His view is, simply, that many other international legal human rights cannot be so justified.

\section{Assessing the rejection of the Mirroring View}

Isolating and throwing doubt on the Mirroring View is one of Buchanan's most valuable and thought-provoking achievements in this book. How successful is his critique? Two strategies seem available to the defender of the Mirroring View. One strategy notes that even for highly demanding "positive" rights, such as the human right to health, it is possible to find underlying moral rights that are solely subject-grounded, such as a right not to have disease inflicted on one, or a right to non- 
burdensome medical assistance in an emergency. Duties entailed by these rights are, I suggest, grounded simply on the importance of the individual's wellbeing or needs, without reference to how such duties serve the wider group. The more demanding international legal human rights — with their correlative duties to set up vaccination programs and the like - could, on this strategy, be seen as somehow expanding on, giving meaning to, or amplifying these underlying moral human rights. True, highly demanding duties to develop expensive health care practices across a society cannot be "solely subject-grounded," but they amplify rights that can.

There are costs to this strategy. For one, it seems to suggest that the more demanding aspects of international human rights law (such as the duty to set up vaccination programs) are somehow less urgent—because less closely reflective of the underlying moral human right — than the less demanding or "negative" aspects, such as the duty not to inflict diseases on people against their will. Nonetheless, rejecting the Mirroring View also seems costly. As David Luban notes, in responding to Buchanan:

No organization called Transnational Legal Claim Rights Watch, or Transnational Legal Claim Rights First, will spring into existence to mobilize shame around their violation. And this is not simply a point about the rhetorical force of labels. It is a point about the moral importance of these rights, the fact that we place great moral weight on them, because we think (rightly or wrongly) that they are closely tied to something basic about humanity as such. ${ }^{4}$

Luban is aware that one could see international legal human rights as justified in "something basic about humanity as such" without grounding them in universal pre-legal moral rights, and he is also in the end not in favor of the Mirroring View. But his point here is that grounding legal human rights in pre-legal moral rights does an especially good job of reflecting the importance we want to give legal human rights.

A second strategy for defending the Mirroring View challenges Buchanan's premise that all pre-legal moral rights must be solely subject-grounded. Perhaps some of my pre-legal moral rights are grounded not by what they do for me, but by what they do for others or for me in combination with others. ${ }^{5}$ In my view, this is a difficult line of response. Few-maybe no-morally justified legal and conventional rights are solely subject-grounded. Even the seemingly individual-focused rights of criminal law are, qua legal rights, grounded not in what they do for a particular individual citizen, but rather in what they do for the generic citizen or the generic person subject to law. We give right-grounding weight to these roles ('citizen', 'person subject to law') because so doing serves the common good, rather than because it serves the individual right-holder. By contrast, I suggest that it is hard to think of pre-legal "natural" rights that are not primarily subject-grounded. Our best candidates for pre-legal rights — rights not to be tortured, rights to emergency assistance- 
do appear to be groundable in large part by what they do for the specific individual right-holder. Your interest in not being tortured, or your need not to be tortured, seems to be the main ground for your having a right not to be tortured. Whether this right serves the common good or the public interest or anything else beyond you appears independent of its grounding: in the case of torture, your interest or need is (normally) sufficient to ground your right.

This issue is muddied by the fact that a person's moral status is defined not just by his or her pre-legal natural rights but also by his or her morally justified legal and conventional rights. It is a moral affront to me when someone paints graffiti on my barn, even though my property rights over the barn are (I just assert, contra Locke) legal creations that do not reflect some underlying "natural" rights over the barn. Similarly, it is a moral affront to me when duties owed to me in my role as lecturer are violated. I am not just the accidental locus for the violation of role-based duties owed in a role-based way to me: because these roles are justified, violating them is a violation of my moral status. By contrast, Buchanan seems to suggest that morally justified legal duties are owed to someone legally without their being owed morally to that person (see especially p. 59).This is misleading. Rather, what we owe morally to someone is defined by the morally justified duties owed to them, including morally justified legal and conventional duties.

But even though morally justified legal and conventional duties are owed morally to their recipients and define their moral status - and even though such duties will correlate with rights that are not solely subject-grounded - this does not help the Mirroring View. For, as suggested earlier, pre-legal natural rights still look solely subject-grounded. If this is correct, then-while Buchanan might have overstated his case by suggesting that legal duties are not owed morally to legal rightholders-Buchanan's argument against the Mirroring View still has force: rights and duties that are not solely subject-grounded do indeed seem not to be pre-legal natural rights. And as Buchanan has shown, many of the duties of international human rights law cannot be solely subject-grounded. This conclusion against the Mirroring View worries me, partly for the reasons outlined by Luban. Buchanan's arguments lay down a challenge to which theorists should respond.

There are further sections of the book that generate additional challenges that I have not mentioned. One is Buchanan's attractive argument against the thesis that "international human rights law and constitutional democracy are incompatible in principle" (p. 245). Another is his sketch of the limits of international human rights law - for example, as a means for tackling environmental problems (pp. 279-292). Yet another is the claim that an international legal human rights regime is not inconsistent with nor need disadvantage "valid collectivist moralities" (p. 257). Buchanan suggests that one might expect the latter inconsistency if the Mirroring View were true, with its assumption that individuals hold pre-legal moral rights. But without the Mirroring View, Buchanan claims that there is no inconsistency between individually held international legal human 
rights and valid collectivist moralities. Buchanan notes that the very idea of rights themselves need not be individualistic: even if rights are, as Ronald Dworkin tells us, by nature trumps over appeals to social utility, they might thereby function to protect "plausible collectivistic values from one extremely implausible collectivistic value, namely, unlimited state power" (p. 262). Buchanan goes on:

When the nation-state claims to be the ultimate source of value, all other groups and all relationships other than that of abject obedience to it are imperiled. Therefore, it is profoundly mistaken to say that the only purpose or even the primary purpose of the international legal human rights regime is to protect individuals from the state. A regime of international legal human rights would be of great value even if all actual moralities were collectivistic (p. 262).

This is highly persuasive, as is the ensuing discussion of how individual rights can often do a better job of protecting groups than group rights (pp. 264-66), and of how the seemingly individualistic dignity-based preambles to international human rights documents are incompatible only with a radical rather than a mild collectivism (pp. 268-69). Part of the value of Buchanan's discussion of collectivistic moralities is that it forces the reader to think carefully about what sort of collectivist one would have to be if one wanted to challenge the defensibility of international legal rights borne by individuals. My sense is that some critics might want to revisit the concern that the very idea of rights is inconsistent with their moral views. Buchanan makes a good job of showing that Dworkin's notion of rights as trumps is not anti-collectivist. But what about the central notion that rights foreground[a specific being (individual or group) as "the right-holder" — the being who qualifies as "wronged" by a violation? Some anti-individualistic critics might claim that better moralities will not involve targeted "wrongable" beings in this way. For example, they might argue that using the notion of rights involves erroneously downgrading the status - in relation to a particular duty-violation — of those who are not right-holders. Consider an attack on a particular person. One line of criticism could be that everyone partakes in victimhood as a result of this act, because the act wrongs the whole world: rights language compels us to focus on the specific rightholder and is in this sense misleading. ${ }^{6} \mathrm{I}$ am not advancing this line of criticism, and no doubt superior arguments can be found. Buchanan's arguments force any such critic to proceed with great care.

I have heard some people question whether international law really is the heart of contemporary human rights: What of activism, journalism, academia, or the bills of rights in national constitutions? What of the fact that many international legal human rights practitioners take themselves to be implementing natural moral rights? However one approaches these questions, Buchanan's book will remain of very great value for showing, in clear language starting from 
plausible premises, how the international legal human rights regime can be defended without appeal to pre-legal moral rights. International human rights law is a surprising and fragile modern legal development. Buchanan's persuasive, thought-provoking defense of it is essential reading for anyone working in the area.

\footnotetext{
${ }^{1}$ The point about vaccination programmes draws on the similar argument in Gopal Sreenivasan, 'A Human Right to Health? Some Inconclusive Skepticism', Aristotelian Society Supplementary Volume, 86 (2012): 239-65.

${ }^{2}$ Buchanan notes on p. 178 (n. 5) that this idea was first introduced in his article (co-authored with Robert Keohane), "The Legitimacy of Global Governance Institutions," Ethics \& International Affairs 20 (2006): 405436.

3It is notable that this wellbeing-based approach seems to be the argument that Buchanan makes for extending equal status rights to beings who lack the capacity to recognise and respond to reason (pp. 138139). If it works for such beings, why not allow that it works for everyone?

${ }^{4}$ David Luban, "Human Rights Foundationalism and Human Rights Pragmatism," in R. Cruft, S. M. Liao, and M. Renzo (eds.) Philosophical Foundations of Human Rights (Oxford University Press, forthcoming 2015). ${ }^{5}$ See the discussion of rights grounded by what they do for people other than the right-holder in Joseph Raz, "Rights and Individual Well-Being," in his Ethics in the Public Domain (Oxford University Press, 1994); and see Simon Cabulea May, "Moral Status and the Direction of Duties," Ethics 123 (2012), and my "Why is it Disrespectful to Violate Rights?," Proceedings of the Aristotelian Society 113 (2013): 201-224.

${ }^{6}$ This is perhaps one way to read Marx's concern that "none of the so-called rights of man goes beyond egoistic man." See Karl Marx, "On the Jewish Question," reprinted in David McLellan (ed.), Karl Marx: Selected Writings, 2nd edn. (Oxford: Oxford University Press, 2000), 46-70, at p. 61. The essay was originally written in 1843 for the Deutsch-französischeJahrbücher.
} 